\title{
Integrated Library Systems
}

compiled by Anna Appleman

Asim, Muhammad and Muhammad Ijaz Mairaj. "Librarians' Perceptions about Adoption and Uses of the Koha Integrated Library Software in Punjab, Pakistan." Electronic Library 37, no. 4 (August 2019):624-35.

Fredericksen, Kristen, Stacey Marien, and Alayne Mundt."Let's Get Technical - Migration Items in Alma." Against the Grain 31, no. 3 (June 2019): 67-68.

Kumar, Vimal and Majeed Abdul. "Data Migration from Legacy Systems to Koha: A Practical Approach." Library Philosophy and Practice (April 2019): 1-17. https://digitalcommons.unl.edu/ libphilprac/2559

Singh, Vandana. "Open Source Integrated Library Systems Migration: Librarians Share the Lessons Learnt.” Journal of Librarianship E Information Science 51, no. 2 (June 2019): 346-55.

Anna Appleman is Cataloger at Columbia Theological Seminary. 